DOI: $10.19195 / 0080-3626.61 .6$

\author{
ОЛЕКСАНДР СЕДЛЯР
}

\title{
ЗАСНУВАННЯ ТА ПЕРШІ РОКИ ДІЯЛЬНОСТІ ТОВАРИСТВА ІМЕНІ МИХАЙЛА КАЧКОВСЬКОГО (1874-1877)
}

\begin{abstract}
Створення Товариства ім. Качковського в 1874 р. зусиллями частини галицьких русинів (москвофілів). Цілі Товариства: поширення знань, підвищення рівня громадянської і національної свідомості серед руських селян та дрібного міщанства. Налагодження в $1874-$ 1877 рр. праці головного осередку, розбудова мережі філій у провінції та розгортання видавничої роботи. Випуск популярних книжок як основний напрям діяльності Товариства.

КЛЮЧОВІ СЛОВА: Товариство ім. М. Качковського, Галичина, галицькі русофіли, видання для народу, Іван Наумович

Założenie Towarzystwa im. M. Kachkovskiego w 1874 r. przez część Rusinów galicyjskich (rusofilów). Cele Towarzystwa: rozpowszechnienie wiedzy, podniesienie poziomu świadomości obywatelskiej i narodowej wśród ruskich chłopów i drobnomieszczaństwa. Uregulowanie w latach 1874-1877 pracy głównego biura, sieci filii na prowincji i działalności wydawniczej. Wydawanie popularnych książeczek jako główny kierunek działalności Towarzystwa.
\end{abstract}

SŁOWA KLUCZOWE: Towarzystwo im. M. Kachkovskiego, Galicja, rusofile galicyjscy, wydawnictwa ludowe, Ivan Naumovych

На початку 1870-х рр. для галицьких русинів все очевиднішою ставала необхідність налагодити активну просвітницьку роботу серед селян та міщан. Новий внутрішньополітичний устрій імперії Габсбургів після 1867 р. 3 широкою автономією коронних країв русини сприймали як менш вигідний порівняно із попередніми часами. Відчутну політично-адміністративну, економічну та культурно-освітню перевагу галицьких поляків вони не мали чим компенсувати. На тлі розгубленості та апатії, які посилилися після виборів до Галицького сейму 1870 р., окремі представники руської інтелігенції почали активно пропагувати ідею регулярної просвітницької роботи з простолюдом. Вони вважали, що через слабкість і пасивність освічених співвітчизників майбутнє руського громадського та національно-культурного життя залежатиме від підтримки передовсім з боку селян та міщан. Ті ж мали ще низький рівень освіти, громадянської та національ- 
ної свідомості і використовували переважно архаїчні практики у господарстві та побуті.

Сама ідея просвіти народу (що значило насамперед просвіту простолюду - селян та міщан, тих, хто не належав до інтелігенції) була, звичайно, зовсім не новою для галицьких русинів початку 1870-х рр. Просвітою через видання популярних та дешевих видань для народу мало займатись створене ще у 1848 р. товариство “Галицько-руська матиця". Однак воно через низку причин (головно через інертність керівництва) не змогло належним чином виконувати своє основне завдання, і це стало очевидним на межі 6070-х років XIX ст. Галицькі українофіли (народовці), безуспішно спробувавши увійти до складу “Матиці”, наприкінці 1868 р. заснували товариство "Просвіта". Воно поступово розвивалося і видавало тисячі примірників популярної літератури для народу. Однак вплив “Просвіти” у першій половині 1870-х рр. не був надто значним, бо більшість активних руських інтелігентів, які комунікували 3 народом, були русофілами і прохолодно ставилися до цього товариства.

Частина русофільських діячів (насамперед провінційних, з-поза Львова) на початку 1870-х рр. поступово дійшла до думки, що варто підтримати регулярне видання спеціальної просвітницької друкованої продукції для народу поза товариствами “Галицько-руська матиця" та "Просвіта". Було успішно реалізовано ідею періодичних видань для простолюду на прикладі газети "Русская Рада" та журналу "Наука". Вони виходили в світ у Коломиї, а їх засновником, фактичним редактором та основним автором був греко-католицький священик Іван Наумович. Ці періодичні видання (з'явилися у 1871 р.) не були першими у галицьких русинів - подібні часописи виходили нетривалий час і в 1860-х рр. - але вони вперше довели (вже на 1873 р.), що подібне видання може стати справді популярним і впливати на свідомість та поведінку селян. Однак періодичні видання не могли повністю задовольнити всі потреби простолюду в читанні - необхідно було подбати і про видання невеликого формату, недорогих книжечок. Подібної практики дотримувалися чеські та словенські просвітні товариства в Австрії, на які орієнтувалися (на жаль, переважно номінально, без видимих практичних результатів) галицькі русини, такі книжечки видавала й "Просвіта". Сам I. Наумович, розуміючи це, анонсував у 1872 р. видання низки таких книжечок під загальною назвою “Читальня". Але як на одну особу йому виявилося забагато праці і видати всі заплановані випуски "Читальні" вчасно він не зміг. Стало очевидним, що подібною роботою мала би займатися група людей, об'єднаних у товариство. До того ж, як слушно згодом зауважив відомий русофільський діяч Осип Мончаловський, “Газета соединяла духовно читателя съ редакціею, книжка соединяла его съ авторомъ, но ни газета, ни книжка не соединяли читателей межи собою. Для такого соединенія оказа- 
лась потреба сотворити що-то иное, а именно Общество или Братство, которое вязало бы просвъщенныхъ и радъющихъ о добрђ своего народа людей и притягало непросвђщенныхъ и несвђдомыхъ въ одно нравственное тъло, бо въ единствђ сила и могущество"1.

Мета цієї статті - розглянути та проаналізувати процес заснування і перші три роки діяльності (від установчих зборів 1874 р. до загальних зборів 1877 р.) Товариства імені Михайла Качковського, створеного групою галицьких русофілів для просвіти народу головно через друковану продукцію. Основну увагу буде приділено організаційному становленню товариства (затвердження статуту, стабілізація роботи головного виділу, формування мережі філій на провінції, налагодження видавничої діяльності) без аналізу його місця серед інших руських громадських організацій, політичних чи національно-культурних переконань окремих його представників тощо. Ці питання варто дослідити в окремих статтях.

Згадане вище організаційне становлення Товариства ім. М. Качковського відбулося протягом 1874-1877 pp. — цим обумовлені хронологічні рамки статті. Окрім того, саме в цей час товариство очолював його ініціатор I. Наумович.

Джерельну базу статті складають насамперед повідомлення у галицькій руській пресі (“Слово”, "Наука”, "Русская Рада”, “Правда”, “Другъ”) про діяльність товариства, а також його видання. На жаль, у збереженому архіві Товариства ім. М. Качковського (ф. 182 Центрального державного історичного архіву України у Львові) документи до середини $1880-\mathrm{x}$ рр. зовсім нечисленні, а про перші роки його існування практично повністю відсутні. Однак детальна інформація у періодиці (передовсім у “Слові”) про загальні збори товариства, засідання його головного виділу (правління) та про заснування філій дозволяє належним чином висвітлити діяльність Товариства ім. М. Качковського та зробити необхідні висновки.

У сучасній науковій літературі початок історії Товариства ім. М. Качковського досліджено недостатньо. Найкраще його розглянув львівський історик Олексій Сухий у присвяченій галицькому русофільству монографії ${ }^{2}$ та в кількох статтях ${ }^{3}$. Хронологічно найновішими $є$ публікації дослідника 3 Тернополя Володимира Лукашіва, який нещодавно захистив дисертацію

1 О.А. Мончаловскій, Памятная книжка въ 25-льтній ювилей Общества имени Михаила Качковского, Львовъ 1899 (Изданіе Общества им. Михаила Качковского, ч. 285), c. $13-14$.

2 О. Сухий, Від русофільства до москвофільства (російський чинник у громадській думиі та суспільно-політичному житті галицьких украӥнців у ХІХ столітті), Львів 2003, с. 312-351 (підрозділ “Товариство імені Михайла Качковського”).

3 О. Сухий, Товариство імені Михайла Качковського: організаційні засади та напрями діяльності, [в:] Україна: культурна спадщина, національна свідомість, державність, Львів 2001, вип. 9, с. 393-403; його ж, Товариство імені М. Качковського: ідеологія та напрями 
3 австрійського періоду історії Товариства ім. М. Качковського ${ }^{4}$, а перед тим опублікував низку статей на цю тему. Він, однак, чомусь у всіх своїх публікаціях розглядав різні аспекти діяльності товариства протягом 40 років (1874-1914 рр.) разом, а це, зрозуміло, не дозволило зупинитися детально на початковому етапі. Варто згадати написану ще на початку 1990-х рр. статтю американського вченого Павла-Роберта Магочія (Магочі) $)^{5}$ та пізнішу статтю львівської дослідниці галицького русофільства Ірини Орлевич ${ }^{6}$. Серед давніх публікацій звернемо увагу на вже цитовану ювілейну книжку О. Мончаловського 7.

Наукова новизна статті полягає передовсім у детальному висвітленні перших, особливо важливих, років діяльності Товариства ім. М. Качковського. Дотепер жоден дослідник не зосереджувався саме на цьому періоді навпаки, вони здебільшого обирали занадто широкі хронологічні рамки (як правило, 1874-1914 pp. — 40 років). Лише О. Сухий комплексно розглянув діяльність товариства за вужчий період (9 років, 1874-1883рр.), однак, на нашу думку, ще більша деталізація дослідження доцільна та необхідна.

Заснування Товариства ім. М. Качковського та його діяльність у 1874-1875 pp. У серпні-вересні 1873 р. у львівському “Слові” з'явилося кілька статей, де обговорювалася можливість створення нового руського просвітницького товариства - Матищі люду. Відповідну ідею подав I. Наумович. Він констатував пасивність і зовсім недостатній рівень забезпечення галицьких русинів популярною літературою з боку “Галицько-руської матиці” і запропонував створити нове товариство, яке б об’єднало русофілів та народовців (українофілів) і зайнялося “изданіемъ полезныхъ, популярныхъ

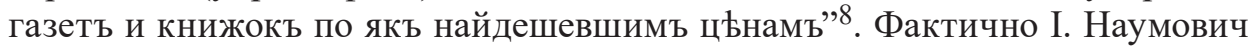
пропонував взяти за зразок подібне чеське товариство (“Matice lidu”) і переформатувати руську просвітницько-видавничу роботу, активізувати іï, залучивши якомога більше здібних людей і відмовившися від партійного

діяльності (70-80-і рр. ХІХ ст.), [в:] Проблеми історії України ХІХ-початку XX cm., Київ, 2004, вип. 7, с. 205-228.

${ }^{4}$ В.Я. Лукашів, Діяльність “Товариства ім. М. Качковського” в Східній Галичині (друга половина $X I X-$ початок $X X \mathrm{~cm}$.): автореферат дисертації на здобуття наукового ступеня кандидата історичних наук, Тернопільський національний педагогічний університет імені Володимира Гнатюка, Тернопіль 2014.

5 П.Р. Магочій, Культурні організації як засіб національного відродження: товариство “Общество имени Михаила Качковского” в Галичині, [в:] Його ж, Галичина (історичні есе), Львів 1994, с. 185-227.

6 І.В. Орлевич, Товариство імені Михайла Качковського в національно-політичному русі галищьких украйнців (1874-1914), [в:] Наука. Релігія. Суспільство, 2009, № 4, с. 101-109.

7 О.А. Мончаловскій, Памятная книжкка въ 25-льтній ювилей...

8 О необходимой потребъ основанія у насъ по примъру Чеховъ "Матицы люду”. Изъ Скалата, “Слово”, 1873, 24 іюля (5 августа) (чис. 87), с. 1. 
поділу. Він також додав, що вже створюється комітет засновників планованого товариства і незабаром буде опубліковано проект його статуту 9 .

Однак проти цього наміру виступили і русофіли в особі редактора “Слова"10, і народовці у своєму часописі "Правда"11. I одні, й інші вважали, що створювати ще одне просвітницьке товариство недоцільно, краще покращувати та розвивати діяльність вже існуючих громадських організацій - відповідно "Галицько-руської матиці" та "Просвіти". І. Наумовича, як видно, наведені аргументи не переконали, однак він, не бажаючи поглиблювати суперечку, дискусію припинив. Напевно тоді він з однодумцями лише відклали до кращих часів ідею нового просвітницько-видавничого товариства для русинів.

Приблизно за рік часу, у серпні 1874 р. у “Слові” з'явилася інформація про перші загальні збори нового товариства, які мали відбутися, та проект його статуту ${ }^{12}$. Мова йшла про Товариство імені Михайла Качковського (в оригінальному написанні “Общество имени Михаила Качковского”). На цей раз I. Наумович (а ініціатором нового товариства був також він) не оголошував передчасно своїх намірів публічно. Очевидно, що реакція принаймні частини лідерів руського громадського життя могла бути негативною, а виступати відкрито проти них провінційному священику не хотілося. Руську публіку поставили перед доконаним фактом, запросивши на перші загальні збори до Коломиї, які відбулися 8 (20) серпня 1874 p.

О. Мончаловський, згадуючи про заснування Товариства ім. Михайла Качковського, повідомив, що його ідею І. Наумович запозичив у словенців. Перебуваючи у Відні як депутат Державної Ради (обраний у 1873 р.), він познайомився із депутатами-словенцями та отримав можливість вивчити досвід словенського просвітницько-видавничого Товариства св. Гермагора (Могорта) (Mohorjeva družba). Воно у 1873 р. мало близько 30 тисяч членів і видавало для них популярну літературу. Вивчивши статут цього товариства, I. Наумович, за словами О. Мончаловського, вирішив заснувати подібне і для галицьких русинів ${ }^{13}$.

Очевидно, не тільки словенське товариство надихнуло I. Наумовича ініціювати створення Товариства ім. М. Качковського - був уже згаданий епізод із вивчення діяльності чеської "Матиці люду”, та й українофільська "Просвіта" не залишилася без його уваги. Але словенський досвід напевне приваблював I. Наумовича: він згадав про Товариство св. Гермагора (Мо-

9 Там само.

10 Въ дъль “Матицьы люду”, “Слово”, 1873, 2 (14) августа (чис. 91), с. 1-2.

11 Матиия люду, “Правда”, 1873, 16 (28) серпня (чис. 13), с. 464-468.

12 Оть Коломыи. (Общество Качковского.), “Слово”, 1874, 27 іюля (8 августа) (чис. 83), c. 3; 30 іюля (11 августа) (чис. 84), с. 2.

13 О.А. Мончаловскій, Памятная книжка въ 25-льтній ювилей..., с. 14. 
горта) у своїй промові на перших загальних зборах ${ }^{14}$, а також описав його переваги у статті, яка пояснювала необхідність створення Товариства ім. М. Качковського уже після загальних зборів ${ }^{15}$. Найбільше йому імпонувало, що словенське товариство мало релігійно-просвітницький характер, а керували ним священики.

Отже, 8 (20) серпня 1874 р. (рівно на другу річницю смерті М. Качковського) у Коломиї за участі 300 осіб відбулися перші, фактично установчі збори товариства його імені. Порядок денний згодом став традиційним на наступних таких зборах: поминальне богослуження за душу М. Качковського, далі вибір голови та секретаря зборів, звіт голови товариства (на перших зборах обговорювали статут), розгляд різних питань учасниками, вибір нового голови товариства та його виділу ${ }^{16}$. У 1874 р. головним питанням було ухвалення статуту. Його проект зачитали на загальних зборах, внесли під час обговорення необхідні доповнення та уточнення і схвалили подати на затвердження до галицького Намісництва у Львові.

За статутом, завданням новозаснованого Товариства ім. М. Качковського було "роспространеніе науки, обычайности, трудолюбія, ощадности и тверезости, гражданского сознанія и всякихъ честнотъ между русскимъ народомъ въ Австріи". Воно мало знаходитися в Коломиї і займатися виданням "популярныхъ, поучительныхъ, дешевыхъ книжокъ религійно-обычайного, наукового, господарского и забавного содержанія", засновувати читальні, крамниці, товариства тверезості, позичкові каси та шпихліри (громадські зернові склади), створювати товариства ремісників та організовувати публічні лекції (відчити). До товариства могли належати всі русини-австрійські піддані; щорічний грошовий внесок складав 1 зр. За умови його сплати члени отримували безкоштовно всі видання товариства. За неморальні вчинки членів 3 товариства могли виключати. Справи товариства вирішували щорічні загальні збори (кожного року — в іншому місті), а поточні справи - виділ товариства, який мав складатися із 12 членів, у т. ч. голови, його заступника і секретаря. Мінімум 12 членів товариства 3 певного населеного пункту мали право створити читальню, яка також отримувала безкоштовно по примірникові всіх видань товариства ${ }^{17}$.

Перші загальні збори обрали виділ (точніше, до затвердження статуту - комітет, який мав би керувати створенням Товариства ім. М. Качковського), який очолив Іван Наумович. До складу цього комітету увійшли

14 Общее собраніе общества имени Михаила Качковского въ Коломыи, “Слово”, 1874, 13 (25) августа (чис. 89), с. 1.

15 Изъ Скалата. (Мысли объ обществъ Михаила Качковского.), “Слово”, 1874, 7 (19) сентября (чис. 99), с. 2-3.

16 Общее собраніе общества имени Михаила Качковского..., “Слово” 1874, 13 (25) августа (чис. 89), с. 1; 20 августа (1 сентября) (чис. 91), с. 2.

17 Там само.

Roczniki Biblioteczne 61, 2017

(C) for this edition by CNS 
10 священиків (у т. ч. і один православний із Буковини) та 4 світські особи ${ }^{18}$. Комітет мав передати статут до Намісництва i, чекаючи на позитивне рiшення крайової влади, приймати нових членів до товариства. Засновники товариства прагнули, аби кількість членів досягла принаймні 10 тисяч — бо лише тоді, як вважалося, воно зможе хоча б частково досягти своєї мети ${ }^{19}$.

Події наступних років показали, що такі сподівання були сильно завищеними і їх неможливо було реалізувати в умовах 1870-х рр. Однак перш ніж перейдемо до розгляду організації та діяльності Товариства ім. М. Качковського в перші роки його існування, звернемо увагу на два важливі моменти: назву товариства та місце його перебування.

I. Наумович та його однодумці вирішили назвати нове товариство іменем судового радника із Самбора Михайла Качковського (1802-1872). Такий вибір був досить дивним. М. Качковський, хоча й був руським патріотом і всіляко підтримував руську літературу в Галичині, однак загалом не вирізнявся ні особливими здібностями, ні (як австрійський чиновник) активною участю в громадському житті. Після смерті навіть його біографія не була добре відома галицьким русинам ${ }^{20}$, а головною заслугою М. Качковського вважали те, що він, відмовляючи собі в усьому, складав гроші зі своєї платні і витрачав їх на розвиток руської літератури і культури. Перед смертю він за заповітом залишив нібито 80 тис. зр. (насправді, як виявилося згодом, менше) на підтримку літературної та іншої діяльності галицьких русинів ${ }^{21}$. Виглядає очевидним, що I. Наумович та інші, називаючи просвітницько-видавниче товариство іменем М. Качковського, непрямо висловлювали претензії на значну спадщину покійного патріота 22 . Однак їхні сподівання не виправдалися і Товариство ім. М. Качковського не отримало очікуваних коштів.

Сам I. Наумович, згадуючи приклад словенського Товариства св. Могорта, писав, що за аналогією варто було б назвати руське товариство іменем хрестителя Русі св. Володимира. Проте засновники товариства вирішили “взяти имя самое популярнђйшее на Руси изъ теперђшности, имя великого патріота, который, якъ для Мадьярь Сеченій, только для русской литературы жилъ, для ней имъніе свое жертвоваль" 23. Теза, що ім’я М. Качковського було найпопулярнішим серед русинів, була кричущим перебільшенням,

18 Львовъ, 10 (22) августа, “Слово”, 1874, 10 (22) августа (чис. 88), с. 1.

19 Там само.

20 Где-щุо изъ житя покойного Михаила Качковского, “Наука”, 1875, Съчень (чис. 1), c. $36-37$.

21 Там само, с. 38.

22 П. Р. Магочій, Культурні організації..., с. 191; О. Сухий, Від русофільства до москвофільства..., с. 312.

23 Изъ Скалата. (Мысли объ обществъ Михаила Качковского.).., с. 3. Що ж до назви товариства іменем св. Володимира, то такий варіант I. Наумович міг відкинути через побоювання звинувачень у русофільстві - київського князя було надто легко асоціювати 
а селяни, наприклад, взагалі не знали про нього, однак сам факт появи такого товариства вплинув на формування історичної пам'яті галицьких русинів кінця ХІХ ст. Цікаво простежити, як особу М. Качковського вводили до віртуального пантеону руських видатних осіб, примножуючи його заслуги і наділяючи його невластивими рисами. Одним із перших публічних проявів такої політики був виступ (власне, проповідь під час богослуження) о. Василя Залозецького на установчих зборах товариства в Коломиї ${ }^{24}$.

Досить незвичним було і місце перебування товариства - Коломия. Всі інші руські товариства всегалицького значення знаходилися у Львові, та й I. Наумович визнавав, що саме адміністративний центр Галичини був би найкращим місцем ${ }^{25}$. На користь Коломиї у нього, як він писав, був лише один аргумент — там вже виходили популярні руські часописи та книжечки, які охоче читали русини. Тобто відомий бренд “коломийського видання для народу” мав би посприяти й книжечкам новозаснованого товариства. Однак була й інша причина, про яку I. Наумович публічно не згадував. Низка його публікацій 1870-х рр. свідчить, хоча й непрямо, що він скептично оцінював можливості львівської руської інтелігенції під проводом вищого духовенства ефективно керувати просвітницьким товариством.

I. Наумович був членом русофільського просвітницького товариства “Галицько-руська матиця" і ще на загальних зборах 1864 р. пропонував, аби воно розпочало видавати популярний часопис для “"потребъ нашого простого сельского народа" 26 . Цього не сталося і на початку 1870-х рр. він зайнявся подібним проектом сам. У той само час (орієнтовно із 1873 р.) діяльність “Галицько-руської матиці” майже призупинилася — цей факт остаточно довів I. Наумовичу необхідність пошуку іншого формату організації просвітницького товариства та його управління. На відміну від “Матиці" нове товариство мало стати масовим, періодично видавати дешеву літературу для селян та міщан і не залежати від інертних лідерів руського громадсько-політичного життя у Львові, які займали високі посади. При цьому йому не слід було, принаймні спочатку, позиціонувати себе як конкурента вже існуючим товариствам — “Матиці” та народовській “Просвіті”. Найкращим варіантом могла видаватися далека від Львова Коломия - там голос ініціатора Товариства ім. М. Качковського мав звучати переконливіше, ніж у Львові.

3 прагненням до всеруської єдності та православ’я. Особа лояльного австрійського підданого і греко-католика М. Качковського не викликала б жодних підозр.

24 Собраніе русскихъ народолюбиъъвъ дня 8. августа въ ияъли основанья человъколюбного общества Михаила Качковского въ Коломыг, “Наука”, 1874, Серпень (чис. 8), с. 340 348. арк. 11.

25 Изъ Скалата. (Мысли объ обществъ Михаила Качковского.)..., с. 3.

26 Центральний державний історичний архів України, м. Львів, ф. 148, оп. 1, спр. 19, 
Наприкінці лютого 1875 р. до товариства надійшов затверджений Намісництвом статут ${ }^{27}$ і стало можливим розпочати активну роботу ${ }^{28}$. На середину лютого 1875 р. вже було 1110 зареєстрованих членів ${ }^{29}$. Почали надходити рукописи для перших книжечок Товариства ім. М. Качковського. Разом із тим було зрозуміло, що цілеспрямована діяльність товариства стане можливою тільки після загальних зборів, які скорегують програму дій та оберуть новий виділ. Перший склад виділу провів після затвердження статуту тільки одне засідання 30 травня (11 червня) 1875 р. На ньому констатували збільшення кількості членів до понад 1600 та надходження від них членських внесків на суму понад 1000 зр., також схвалили до друку першу книжечку видань товариства - “Съ Богомъ!” І. Наумовича і вирішили провести загальні збори у Галичі ${ }^{30}$.

Перед загальними зборами у “Слові” з’явилася стаття І. Наумовича з міркуваннями про розвиток Товариства ім. М. Качковського. Автор спробував окреслити найголовніші проблеми товариства — ця стаття вже не була такою оптимістичною, як ті, що писав I. Наумович у 1874 р. Констатуючи зростання кількості членів товариства, його голова відзначив три найбільші проблеми: 1) пасивність потенційних авторів і, як наслідок, брак рукописів для видання з багатьох важливих тем; 2) необхідність організувати розповсюдження видань товариства через спеціальних продавців (кольпортерів), очевидно, мандрівних, та агентів; 3) необхідність по-новому організувати роботу виділу товариства, коли б його голова постійно перебував у Коломиї, а секретар займався справами фахово і на платній основі. На завершення статті він ще раз висловився за перебування товариства в Коломиї і рішуче відмовився далі його очолювати через велику відстань від Скалата, де мешкав, до Коломиї і неможливість відвідувати засідання виділу ${ }^{31}$.

Завершили процес інституційного оформлення Товариства ім. М. Качковського загальні збори у Галичі, які відбулися 12 (24) серпня 1875 р. за

27 “Русская Рада", 1875, 17 лютого (ст. ст.) (чис. 4), с. 31. Керівники товариства подали статут на затвердження ще 17 (29) вересня 1874 р., однак перший його варіант відхилили (через крамниці, на заснування яких потрібен був дозвіл міністерства, та ін.). Внесення поправок та повторне подання до Намісництва відклали затвердження статуту до початку 1875 р. (“Русская Рада”, 1874, 18 (30) вересня (чис. 18), с. 151; О обществъ Михаила Качковского, "Русская Рада", 1875, 1 съчня (чис. 1), с. 6).

28 Статут 1875 р. опубліковано: Статуты Общества имени Михаила Качковского въ Коломыг, [в:] И. Наумовичъ, Съ Богомъ!, Коломыя 1875, (Изданій Общества имени Мих. Качковского въ Коломыъ, ч. I), с. 11-21.

29 “Слово”, 1875, 6 (18) февраля (чис. 14), с. 3.

30 “Слово”, 1875, 31 мая (12 іюня) (чис. 59), с. 3.

31 Изъ Скалата. (О предстоящемъ собраніи членовъ Общества имени Михаила Качковского въ Галичґ.), “Слово”, 1875, 8 (20) іюля (чис. 73), с. 1-2. 
участі майже тисячі осіб ${ }^{32}$. Після обов'язкового богослуження розпочалося засідання звітом секретаря виділу о. Іларіона Шушковського. Він повідомив, що число членів товариства зросло до 2600, причому за останні два дні записалося 430 нових членів. Видатків було 1987 зр. 92 кр., головно на папір та друк перших трьох книжечок. Загалом його виступ був оптимістичним, секретар товариства висловив сподівання, що до кінця 1875 р. кількість членів може зрости до 5000, що дозволить значно активізувати видавничу діяльність ${ }^{33}$.

Далі загальні збори ухвалили запровадити деякі зміни до статуту товариства. Зокрема, вирішили внести пункт про можливість організації під час загальних зборів виставок господарських знарядь, а також, після тривалої дискусії, ухвалили ввести до структури Товариства ім. М. Качковського філії ${ }^{4}$. Прихильники їх створення аргументували свою позицію тим, що філії привернуть до себе більше людей, активізують громадське життя на провінції та полегшать розповсюдження видань товариства, а противники цієї ідеї звертали увагу на зайве збільшення діловодства і висловлювали сумнів, чи знайдеться достатньо людей на місцях, аби успішно вести справи філій ${ }^{35}$. Подальші події показали, що всі ці аргументи були небезпідставними.

Незважаючи на спротив I. Наумовича, загальні збори в Галичі знову обрали його головою Товариства ім. М. Качковського. До виділу (разом із заступниками виділових) увійшло 14 осіб, із них 6 священиків. Автор звіту в "Науці" прямо написав, що під час вибору голови “собраніе руководилося тоิлько самымъ чувствомъ, а не практичностію”, а сам І. Наумович погодився із вибором дуже неохоче ${ }^{36}$. Загалом він залишився номінальним головою, хоча й намагався брати участь у роботі виділу.

Таке емоційне і загалом безвідповідальне рішення загальних зборів свідчило про те, що організаційне становлення товариства ще не завершилося. Найбільшою проблемою була неготовність виділу до організованої і наперед продуманої повсякденної роботи. Навіть згадані загальні збори не були сплановані та проведені належним чином (наприклад, виділ виніс на

32 Отчетъ изъ второго генерального собранія общества имени Михаила Качковского, происходившого во вторникъ 12 (24) с. м. въ городъ Галичь, “Слово”, 1875, 14 (26) августа (чис. 88), с. 1-2; 19 (31) августа (чис. 89), с. 1. "Правда” подає кількість учасників зборів як 600-700 (Загальні збори товариства Михаіла Качковского, “Правда”, 1875, 3 (15) вересня (чис. 17), с. 701).

33 Отчеть изъ второго генерального собранія..., “Слово”, 1875, 14 (26) августа (чис. $88)$, c. 1 .

34 Там само.

35 Первое загальное собраніе общества имени Михаила Качковского, “Наука”, 1875, Серпень (чис. 8), с. 338-339.

36 Там само, с. 341-342.

Roczniki Biblioteczne 61, 2017

(C) for this edition by CNS 
затвердження зборів зміну до статуту щодо виставок господарських знарядь, але формулювання відповідного пункту не запропонував і т. п.), що відзначали і русофіли, i народовці ${ }^{37}$. До цього додавалося невміння організувати плідну дискусію, схильність промовців до довгих, нудних і малозначущих виступів, які селяни розуміли погано. Це ж відзначив і відомий громадський діяч із Наддніпрянської України Михайло Драгоманов, який відвідав збори у Галичі ${ }^{38}$.

Новий склад виділу отримав справи від попередників у невпорядкованому стані, що загрожувало успішному розвиткові товариства ${ }^{39}$. Секретарем 31 жовтня 1875 р. обрали Івана Левицького, який почав отримувати платню за свою роботу ${ }^{40}$ i зайнявся передовсім впорядкуванням документації товариства ${ }^{41}$ та експедицією нових видань (до кінця року вийшли чотири книжечки). Швидко виявилося, що виділ переповнений людьми, які не могли (або й не хотіли) займатися справами товариства. Фактично регулярно працював один секретар, а він ніяк не міг належним чином і вчасно виконати всю необхідну роботу. Як наслідок, виділ Товариства ім. М. Качковського ухвалив на засіданні 14 (26) грудня 1875 р. скликати надзвичайні загальні

37 Там само, с. 337; Загальні збори товариства Михаіла Качковского..., с. 703. Кореспондентові “Слова" селяни, що прибули на збори, говорили прямо: "Не было господаря" (Отъ Галича. (Гадки по поводу собранія общества имени Михаила Качковского въ Галичъ.), “Слово”, 1875, 28 августа (9 сентября) (чис. 93), с. 2).

38 “Оратори ж галицькі страшно незручні: не вміють говорити коротко, образно і просто про діло, а несуть хрії, зложені по старій риториці, — довжезні, бліді, темні і страшенно скучні. Витерпіти галицький мітинг — тяжка робота навіть для вишколеної людини, тим паче для простої. До того оратори тов[ариства] Качковського, як спеціальні твердоруси, навмисне говорили таким язиком, що й мені, напр., було часто дуже важко їх розуміти. Я навмисне старавсь міститись серед мужиків [...]. Ті “хлопи” дуже пильно прислухались до промов: видимо, щиро заінтересовані були мітингом, але дуже мало розуміли промови" (М.П. Драгоманов, Австро-руські спомини (1867-1877), [в:] Його ж, Літературно-публіичистичні праці: у 2 т., Київ 1970, т. 2, с. 255-256).

39 Серед паперів I. Наумовича збереглася його записка, яка свідчить про безлад у справах Товариства ім. М. Качковського в другій половині 1875 р.: “Съ обществомъ Качковскаго ужасныи клопоты! Вђроятно, то розпадется. Посль Шушковскаго нерядънья не возможно въ ладъ дъло привести" (Львівська національна наукова бібліотека ім. В. Стефаника НАН України, відділ рукописів, ф. 2, од. зб. 126 / п. 15, арк. 23).

40 О обществъ Михаила Качковского, "Русская Рада", 1875, 17 вересня (чис. 18), с. 141. Платня секретаря товариства складала 600 зр. на рік. Пізніше (з 1876 р.) платню зменшили.

41 “[...] наступили великіи баламутства въ рахункахъ, и треба було новому секретарю Левицкому добре присђсти коิлька мњсяцЊвъ, посправляти всђ книги, друксорты и пр., и днями, и ночами трудитися, щобы составити поименный списъ членоิвъ ведля азбуки, другій ведля почтъ, третій касовый, дальше всь рахунки съ печатнею, съ купцями и пр., а при тоิмъ вести численную кореспонденцію съ сторонами" ([И. Наумовичъ], О обществъ Михаила Качковского, “Наука”, 1876, Съчень (чис. 1), с. 48-49). 
збори і затвердити на них перенесення товариства до Львова ${ }^{42}$. I. Наумович у пресі визнав свою помилку щодо розміщення товариства в Коломиї, висловився за перенесення його офісу до Львова, а також закликав членів товариства ефективніше провести нові загальні збори ${ }^{43}$.

Отже, Товариство ім. М. Качковського з початком 1876 р. отримало ще один шанс "перезавантажити" свою діяльність. Короткий коломийський період його історії закінчився без особливих успіхів. О. Мончаловський згодом написав, що “Дъятельность Общества во время его пребыванья въ Коломыъ можно назвати приготовительною. Живая-же и плодотворная дъятельность Общества начинаеся съ перенесеньемъ его во Львовъ ${ }^{44}$.

Продовження організаційної розбудови Товариства ім. М. Качковського у 1876-1877 pp. 8 (20) січня 1876 р. у Львові за участі лише 69 членів відбулися надзвичайні загальні збори Товариства ім. М. Качковського ${ }^{45}$. На них і голова товариства I. Наумович, і секретар I. Левицький констатували, що воно “въ моральномъ отношеніи” процвітає і вже встигло здобути собі довіру та пошану серед народу. Однак у Коломиї бракує активних людей для розвитку товариства, натомість вони знайдуться у Львові — тому необхідно перемістити офіс до адміністративного центру Галичини. Виявилося також, що кількість членів товариства зросла до 3562, хоча 3 них тільки 2565 заплатили членські внески ${ }^{46}$.

Після досить жвавої дискусії загальні збори ухвалили перенести місце розташування Товариства ім. М. Качковського до Львова і обрали новий виділ на чолі знову із I. Наумовичем. Парох зі Скалата без ентузіазму був змушений прийняти цей вибір, бо “такъ собъ желае нароิдъ, а воля народа свята, и о. Наумовичъ мусьвъ ей поิддатися" "47. До виділу увійшли 13 осіб, у т. ч. 4 священики. Заступником голови обрали д-ра медицини Свгена Мироновича, секретарем знову I. Левицького (пізніше його замінив Антін Дольницький), скарбником редактора “Слова” Венедикта Площанського,

42 Изъ Коломыи. (Засъданіе выдъла общества имени Михаила Качковского.), “Слово”, 1875, 23 декабря (4 января 1876) (чис. 141), с. 2-3.

43 “Теперь бы лишь треба, щобы нашиิ народолюбцъ роздумали тую важную ръчь и щобы на будущомъ загальномм собранію не робили такъ, якъ въ Галичи, що було много крику, а мало ръчи. Дорогій часъ зоийшовъ на непотръбныхъ суперечкахъ, а найважнъйшиิ дъла не прійшли до бесьды. Виною сего було правда то, що выдъль не составивъ програма" (И. Наумовичъ, О обществъ Михаила Качковского, "Русская Рада", 1875, 18 грудня (чис. 24), c. 190).

44 О.А. Мончаловскій, Памятная книжка въ 25-льтній ювилей..., с. 23.

45 Там само, с. 22-23. "Слово” повідомило, що учасників було близько 100 (“Слово”, 1876, 10 (22) января (чис. 5), с. 3.

46 Генеральное собраніе членовъ общества имени Михаила Качковского, “Слово”, 1876, 10 (22) января (чис. 5), с. 1; 13 (25) января (чис. 6), с. 1.

47 [И. Наумовичъ], О обществъ Михаила Качковского, "Наука", 1876, Съчень (чис. 1), c. 50 .

Roczniki Biblioteczne 61, 2017

(C) for this edition by CNS 
а контролером чиновника Ставропігійського інституту Олексія Щербана. Як коротко підсумувало “Слово” відразу після зборів, “переселеніемъ во Львовъ спаслось общество оть засньченія" 48 .

Новий виділ дочекався затвердження Намісництвом змін до статуту товариства (це сталося 17 (29) лютого 1876 р.) ${ }^{49}$ і розпочав свою діяльність. Важливим доповненням у статуті стала можливість товариству створювати свої філії. Головно саме цим поза упорядкуванням діловодства на новому місці перебування та виданням книжечок став займатися виділ 1876 р. Він 3 березня по серпень провів 11 засідань (для порівняння: перший склад виділу $1874 / 75$ рр. відбув два засідання, другий склад у 1875 р. — три) ${ }^{50}$. Вже на засіданні 1 червня 1876 р. члени виділу із задоволенням прийняли до відома повідомлення Є. Мироновича (а він фактично виконував обов’язки голови товариства), що “члены на тек. годъ вступаютъ безпрерывно, что прежніи долги за минувшій годъ сплачаются и что вообще прежніи раны общества начинають успъшно гоитися" 51 , а на початку липня виділ чітко дав зрозуміти русинам, що “наше Общество, мимо того, что текущій годъ есть для него еще годомъ организаиійнымъ, сдобываеть себъ помалу крђпкій терренъ въ Галичинъ и пользуется симпатіею на Буковинъ и Угорской Руси" ${ }^{\prime 2}$. Загалом настрій був оптимістичним, товариство розпочало працювати набагато активніше, ніж у 1875 р., прогноз на майбутнє був позитивним.

Оптимізм викликали насамперед зростання кількості членів та регулярна поява все нових філій на провінції. Виділ розпочав займатися організацією філій вже у березні 1876 р., а там, де важко було б їх відразу заснувати, мали б з'явитися “агенты общества, на которыхъ руки книжки высылатись будутъ и которыи собирати будутъ вкладки отъ членовъ "53. На початку квітня у газетах опублікували список із 22 таких агентів, причому 19 з них були греко-католицькими священиками, а ще один - студентом-теологом ${ }^{54}$.

На початку травня 1876 р. у “Слові” з’явилася відозва від виділу Товариства ім. М. Качковського. У ній був заклик до галицьких русинів створювати філії товариства і наголошувалося на їх особливій ролі та великому значенні: “'Задача филій есть дуже важна — важньйша може, чьмъ центрального выдЂла, именно для того, что филіи будутъ безпосредственно стыкатись съ

48 “Слово”, 1876, 10 (22) января (чис. 5), с. 3.

49 Статут Товариства ім. М. Качковського у редакції 1876 р. опубліковано: Cmamymы Общества имени Михаила Качковского во Львовъ, [в:] И. Наумовичъ, Горитъ!, Львовъ 1876, (Изданій Общества имени Мих. Качковского во Львовъ, ч. V), с. 52-64.

50 О.А. Мончаловскій, Памятная книжка въ 25-лътній ювилей.., с. 21-23.

51 “Слово”, 1876, 22 мая (3 іюня) (чис. 59), с. 3.

52 “Слово”, 1876, 28 іюня (10 іюля) (чис. 73), с. 3.

53 “Слово”, 1876, 11 (23) марта (чис. 30), с. 3.

54 “Слово”, 1876, 27 марта (8 апрьля) (чис. 36-37), с. 5; Общество Качковского, "Наука", 1876, Марть (чис. 3), с. 144. 
членами округа своего, что имъють сльдити за нуждами народа, думати надъ средствами усуненья тъхъ же и ставити внесенія отвђтныи до центрального комитета, который заниматись будетъ только редакціею и высылкою сочиненій и контролею филій, дальше, что только филіи могутъ успъшно заниматись основываніемъ читальней, обществъ тверезости, громадскихъ касъ пожичковыхъ и ссыповъ хлеба по селамъ своего округа, что вконцъ только общіи собранія филіальныхъ членовъ подадутъ возможность народу высказати свои нужды, подати и средства до заспокоенія ихъ и въ загаль поняти свое достоинство, почувствовати въ себъ гражданина свободной державы, почувствовати и высшіи, духовыи потребы”55.

Першу філію Товариства ім. М. Качковського заснували в Станіславові 7 (19) квітня 1876 р. До загальних зборів 10 (22) серпня 1876 р. з'явилося ще 11 філій — у Перемишлі, Золочеві, Калуші, Сокалі, Яворові, Жидачеві, Дрогобичі, Бродах, Скалаті, Стрию та Рогатині. Пізніше, до наступних загальних зборів 1877 р. заснували філії у Глинянах, Самборі, Снятині, Раві Руській, Коломиї, Тернополі та Бережанах. Таким чином всього у 1876-1877 pр. створили 19 філій. Варто відзначити, що подібний досвід масового створення філій був першим серед українських громадських організацій - станом на 1876 р. ні “Галицько-руська матиця", ні “Просвіта" філій не мали.

Окрім інших завдань, філії мали рекламувати саме товариство. Чи не найпершим результатом їх появи стало значне збільшення членів Товариства ім. М. Качковського у відповідних регіонах. Установчі збори кожної філії загалом у мініатюрі нагадували загальні збори товариства — розпочиналися богослуженням, далі була вступна промова про завдання товариства і роль М. Качковського у руському громадському та національно-культурному житті, потім обирали виділ філії та обговорювали різні пропозиції членів товариства. Перед зборами філії до товариства записувалися нові члени у 1876-1877 рр. їх було, як правило, кілька десятків (найчастіше від 30 до 50), інколи їх число доходило до сотні. Внаслідок цього кількість членів товариства у певному повіті різко зростала на третину, половину, а то і більше.

Цікаво простежити склад виділів філій. До них, звісно, часто потрапляли випадкові люди, які потім не займалися громадськими справами, однак аналіз соціального складу виділів покаже, кого русини другої половини 1870-х рр. бачили лідерами просвітницького руху і загалом громадського життя на провінції. Як правило, до виділів філій Товариства ім. М. Качковського обирали голову, 8 основних членів і 4 їх заступників (могли брати участь у засіданнях за відсутності основних членів), хоча були й винятки. Отже, у 1876-1877 рр. обрали виділи 19 філій товариства, до них увійшло

55 Изъ Львова. (Основаніе филій общества им. М. Качковского.), “Слово”, 1876. 27 апрьля (9 мая) (чис. 49), с. 2. 
247 осіб (основних членів та заступників) ${ }^{56}$. Соціальний склад членів виділів філій Товариства ім. М. Качковського першого скликання наступний: священиків - 95 (38,5\%), селян - 71 (28,7\%), міщан — 42 (17\%), вчителів міських і сільських народних шкіл - 14, гімназійних вчителів (мирян) - 10 (разом зі вчителями-священиками - 14), судових чиновників - 7, інших - 8. Як бачимо, переважали священики, селян і міщан разом було трохи менше половини від усіх членів виділів, а вчителів було небагато - всіх разом близько $10 \%$.

Однак де-факто члени виділів мали різний вплив. Керівна роль була за священиками, а селян та міщан обирали переважно заступниками основних членів виділів. Якщо простежити соціальний склад основних членів (132 особи, дані доступні по виділах 15 з 19 філій), то картина буде такою: священиків - 59 (44,7\%), міщан — 22 (16,7\%), селян — 22 (16,7\%), вчителів народних шкіл - 11, гімназійних вчителів - 8, судових чиновників - 5 , інших - 5. Таким чином, селяни та міщани складали лише третину основних членів виділів, а домінувала в них інтелігенція. Очолювали філії майже виключно священики - такою була ситуація у 18 випадках із 19.

Отже, хоча головний виділ Товариства ім. М. Качковського у Львові складався передовсім зі світських осіб і майже повністю з представників інтелігенції, то провінційні осередки товариства очолювали і фактично ними керували греко-католицькі священики. Діяльність філій не була рівномірною - деякі з них не робили нічого або майже нічого, інші завдяки активності окремих членів виділів займалися лише розповсюдженням видань товариства і тільки кілька філій провадили різносторонню діяльність. Найактивнішими та найуспішнішими філіями Товариства ім. М. Качковського у другій половині $1870-\mathrm{x} \mathrm{pp.} \mathrm{були} \mathrm{станіславівська} \mathrm{і} \mathrm{сокальська.} \mathrm{Головною}$ проблемою філій був, як і очікувалося, брак людей, готових регулярно та кваліфіковано (і безоплатно) займатися їх справами.

Що ж до читалень, то вони у другій половині 1870-х рр. ще не входили до структури Товариства ім. М. Качковського та існували як окремі громадські організації зі своїми статутами. Вони лише отримували безкоштовно видання товариства, якщо були засновані принаймні 12 його членами.

10 (22) серпня 1876 р. у Стрию відбулися чергові, вже четверті (або, якщо не рахувати установчі збори в 1874 р., треті), загальні збори Товариства ім.

56 “Слово”, 1876. 15 (27) апръля (чис. 44), с. 2; 24 апрђля (6 мая) (чис. 48), с. $3 ; 4$ (16) мая (чис. 52), с. $3 ; 6$ (18) мая (чис. 53), с. $3 ; 3$ (15) іюня (чис. 63), с. $2 ; 8$ (20) іюня (чис. 65), с. 2; 10 (22) іюня (чис. 66), с. 2; 17 (29) іюня (чис. 69), с. 2; 22 іюня (4 іюля) (чис. 71), с. 1; 10 (22) іюля (чис. 78), с. $3 ; 9$ (21) августа (чис. 90), с. $3 ; 21$ декабря (2 января 1877) (чис. 142), с. 3; 1877, 11 (23) января (чис. 3), с. 1; 18 (30) января (чис. 6), с. 1; 17 февраля (1 марта) (чис. 18), с. 3; 27 іюня (9 іюля) (чис. 70), с. $3 ; 19$ (31) іюля (чис. 79), с. 2; О.А. Мончаловскій, Памятная книжка въ 25-льтній ювилей..., с. 77, 79, 81, 95. 
М. Качковського за участі кількох сотень осіб 57 . Звіт діючого виділу товариства звучав дуже оптимістично: кількість членів зросла до 4791, відкрито 12 філій, прибутки товариства склали суму 2403 зр. 03 кр., а видатки - тільки 1345 зр. 15 кр., тому 1057 зр. 87 кр. поклали на депозит. Видання товариства почали з'являтися регулярно, щомісяця, а довіра в народу така, якою не може похвалитися жодне інше товариство ${ }^{58}$. I. Наумович, якого знову переобрали головою Товариства ім. М. Качковського, після зборів у “Науці" підкреслив, що не сподівався такого швидкого зросту товариства при всіх його недоліках і висловив переконання, що і в майбутньому все буде добре ${ }^{59}$.

Загальні збори в Стрию не ухвалили особливо важливих рішень для розвитку товариства. Було обрано голову (I. Наумовича) та новий склад виділу. Як виявилося згодом, заступником голови знову став Є. Миронович (незадовго його замінив В. Площанський), секретарем - чиновник Інституту “Народний Дім" Теодор Олійник, касиром - податківець-емерит Дмитро Біленький, контролером - о. Іларій Пачовський з Наварії ${ }^{60}$. Саме вибори виділу Товариства ім. М. Качковського викликали різку критику з боку народовців та руської молоді, яка гуртувалася навколо товариства “Академическій кружокъ”. Молодь пропонувала своїх кандидатів до виділу, найгостріша дискусія велася щодо кандидатури Івана Франка, тоді студента Львівського університету та бібліотекаря “Кружка". Врешті-решт її просто не поставили на голосування, а натомість обрали осіб, які, на думку редакції “Друга” (часопису “Академического Кружка") або не матимуть часу, або просто не зможуть належно займатися справами товариства ${ }^{61}$.

Виражено критичною була й реакція на збори в Стрию і від народовської “Правди". Зробивши спочатку цілком слушний закид організаторам зборів за занадто розтягнуту в часі їх програму, “Правда” наголосила на вкрай низькій ефективності таких загальних зборів з точки зору популяризації народної просвіти ${ }^{62}$. Учасники зборів-селяни, як і у Галичі, на час обговорення різних питань вже встигали втомитися від тривалого богослуження, різних вітальних промов, слухання довгого звіту тощо. Натомість під час виборів

57 Кореспонденти "Правди" писали, що учасників було 400 (Загальні збори Общества имени М. Качковского в Стрию, “Правда”, 1876, 19 (31) серпня (чис. 16), с. 636; Из Стрийського Підгіря, “Правда”, 1876, 3 (15) вересня (чис. 17), с. 671), “Другъ” подав їх кількість як 700-800 (“Другъ”, 1876, 15 (27) серпня, с. 256), а “Слово” вказало виразно перебільшене число 1500 (Третье генеральное собраніе общества имени Михаила Качковского, “Слово”, 1876, 12 (24) августа (чис. 91), с. 1).

58 Третье генеральное собраніе..., с. 1.

59 [И. Наумовичъ], Общество Михаила Качковского, “Наука”, 1876, Серпень (чис. 8), c. $273-280$.

60 “Слово”, 1876, 18 (30) сентября (чис. 106), с. 3.

61 Другъ, 1876, 15 (27) серпня, с. 256.

62 Загальні збори Обществв имени М. Качковского в Стрию..., с. 636-637. 
нового виділу та дискусій їх особливо і не питали, і не слухали. Виявилося, що лідери товариства просто не готові до обговорення незручних для них питань. Дописувач до “Правди” зі Стрийщини підсумував, що збори для селян виявилися нецікавими і справили на них загалом негативне враження ${ }^{63}$.

Новий виділ Товариства ім. М. Качковського, який діяв у 1876-1877 pp., своїм основним завданням вважав закінчення реорганізації товариства після переїзду до Львова і закладення міцної основи на майбутне ${ }^{64}$. Станом на початок 1877 р. реорганізацію майже вдалося завершити і після констатації: “всђ дъла нашего Общества направлены уже рђшительно на лучшій путь” головний виділ вирішив, окрім адміністративних справ, займатися головно покращенням змісту видань товариства ${ }^{65}$. Загалом поруч із обговоренням видавничих питань члени правління Товариства ім. М. Качковського займалися справами філій (їх, як виявилося, довелося перезаснувати на нових умовах), розповсюдженням книжечок та нагадуванням боржникам про необхідність сплатити членські внески ${ }^{66}$.

П’яті загальні збори Товариства ім. М. Качковського відбулися 20 вересня (2 жовтня) 1877 р. у Львові, під час промислово-господарської виставки. Їх учасники (близько 200) ухвалили кілька змін до статуту товариства. Найголовнішими з них були позбавлення членства тих осіб, які протягом 6 місяців після закінчення адміністративного року (починався 3 (15) травня) ${ }^{*}$ не

63 “Хочу ще згадати, яке вражінє зробили сі збори на селян. Коротко сказавши: дуже некористне. Всё, що на засіданю перед полуднем и по полудні при спорах над вибором виділу було наговорено, не мало жадного интересу для селян, з котрих и блисько половина в часі вибировоі борби опустила салю. Деякі виступали навіть на зборах з закидами, що пани сваряться непотрібно, а не оглядаються на селян, а також з закидами на недбалість многих священиків о просвіту и добро народа" (Из Стрийського Підгіря..., с. 673).

64 “Касательно дотеперђшней дъятельности настоящого выдъла примътимъ, что главною и первьйшею заботою его до сихъ поръ было: изльчити Общество изъ тяжкихъ и опасныхъ недуговъ и ихъ посльдствій, съ якими переселилось оно годъ тому назадъ во Львовъ, тоже основати якъ найбольше филій, перевести верификацію членовъ, управильнити розвظтвленную администрацію, поплатити все, что кому принадлежало, привести касовыи дъла - nervus rerum - въ ладъ и вообще скрьпитись такъ, чтобы въ будущемъ невозможны были прежніи недуги” (“Слово”, 1877, 29 января (10 февраля) (чис. 11), с. 3).

65 Там само.

66 Отчетъ Комитета Общества им. М. Качковского о дъятельности его за время отъ 10 (22) августа 1876 по 20 сентября (2 окт.) 1877 г., составленный и предложенный въ пятомъ генеральномъ собраніи членовъ Общества во Львовъ мъстопредсъдателемъ Венед. М. Площанскимъ, “Слово”, 1877, 27 сентября (9 октября) (чис. 105), с. 1-2.

* 3 (15) травня як дату скасування панщини в Галичині у 1848 р. галицькі русини вважали своїм національним святом. Правда, визнання її початком адміністративного року Товариства ім. М. Качковського породило чимало плутанини і непорозумінь із членами, адже чимало 3 них орієнтувалися щодо сплати щорічного внеску та отримання книжечок або на початок календарного року, або на час загальних зборів, які відбувалися наприкінці серпня чи у вересні.

Roczniki Biblioteczne 61, 2017

(C) for this edition by CNS 
заплатили свій річний внесок, а також дозвіл філіям засновувати крамниці67. Кількість членів товариства зросла до приблизно $6500^{68}$, але через недостатню сплату ними внесків (надійшло 4061 зр. 90 кр.) ${ }^{69}$ фінансове становище товариства хоча й було задовільним, але вже не таким добрим, як у 1876 р.

Також традиційно обрали голову (ним став редактор “Слова” В. Площанський, а I. Наумовича оголосили “покровителем” товариства) і новий склад виділу. В цілому він, незважаючи на нові прізвища, залишився на рівні попереднього, що викликало вже звичну критику народовців ${ }^{70}$. Вони також дуже скептично оцінили результати роботи товариства, вважаючи, що воно "не поступає наперед, а дотеперішні мнимі успіхи ёго суть тілько поверховні и без всякої користі для руського народу"71. Хоча такі висновки можна пояснити міжпартійною конкуренцією між народовцями та русофілами, однак вони були значним чином слушними. Товариство ім. М. Качковського станом на кінець 1877 р. відлагодило свою організаційну структуру та діяльність, але можливості для подальшого розвитку були, як виявилося згодом, невеликими.

Видавнича діяльність Товариства ім. М. Качковського ${ }^{*}$ Товариство після затвердження статуту на початку 1875 р. нарешті змогло розпочати виконувати основне своє завдання - видавати популярні книжечки для просвіти народу. Саме на їх виготовлення члени товариства головно і сплачували 1 зр. річного внеску, а тому й нетерпляче очікували результатів. Видання таких книжечок не було чимось новим для галицьких русинів. Окрім здобутків інших народів Австро-Угорщини у цій сфері, Товариство ім. М. Качковського могло брати приклад із досить успішних подібних видань “Просвіти”, а також (і насамперед) скористатися досвідом підготовки коломийських періодичних і неперіодичних публікацій для народу I. Наумовича та М. Білоуса.

67 Пятое генеральное собраніе членовъ Общества имени Михаила Качковского во Львовъ 20 сентября (2 октября), “Слово”, 1877, 22 сентября (4 октября) (чис. 103), с. 2.

68 Отчеть Комитета Общества им. М. Качковского... с. 1.

69 Пятое генеральное собраніе... с. 2. Філії отримували на свої потреби $10 \%$ членських внесків, а тому їх загальна сума могла бути до 4500 зр. Такою ж (максимум 4500) була кількість реальних (активних) членів Товариства ім. М. Качковського.

70 Слабким місцем Товариства ім. М. Качковського “Правда” назвала “брак людей помимо великого числа членів; брак людей щирих, спосібних и охочих до праці для народу, особливо в центральнім виділі! Перегляньмо на пр. теперішній центр. виділ, а побачимо самі нулі без цифри, самих людей, не маючих навіть понятя о так великій справі, як просвіта народу [...]” (“Общество имени Михаила Качковского”, “Правда”, 1877, 3 (15) жовтня (чис. 19), с. 744).

71 Там само, с. 743.

* У даній статті буде проаналізовано лише організацію видавничої діяльності Товариства ім. М. Качковського. Тематика та зміст його видань стануть предметом дослідження однієї з наступних статей автора.

Roczniki Biblioteczne 61, 2017

(C) for this edition by CNS 
Про першу книжечку, яка мала вийти незабаром, оголосили ще на початку березня $1875 \mathrm{p}^{72}$ Проте вона вийшла в світ лише в середині липня ${ }^{73}$, а згодом виявилося, що головний виділ має проблеми із задоволенням запитів членів товариства на нові видання. У 1875 р. не вдалося налагодити регулярний випуск книжечок Товариства ім. М. Качковського через кілька причин: по-перше, організація самого товариства, про що йшлося вище, не була завершена; по-друге, бракувало відповідних текстів до публікації ${ }^{74}$; по-трете, виділ вирішив друкувати перші книжечки величезним накладом в 10 тис. примірників ${ }^{75}$, що швидко вичерпало наявні кошти товариства.

Рішення про такий великий наклад видань виявилося помилковим, і це згодом визнало керівництво Товариства ім. М. Качковського. Як воно з'явилося? Це була ухвала головного виділу на засіданні 30 травня (11 червня) 1875 p., поруч із рішенням виплачувати авторам гонорар у розмірі 10 зр. від друкованого аркуша ${ }^{76}$. Мотивація ㄲï була наступною: “Общество крђпко въритъ въ будущноิсть русского народа, надъючися на такъ великое число [тобто 10000 - О.С.] приступити маючихъ членоิвъ, а надђеся по той причинъ, бо видить на дълъ, що где лишь священникъ додасть собђ хоть не много труда, зъ одного прихода вписуются по коิлькадесять членоิвъ" 77 . Як виявилося згодом, такий оптимізм був невиправданим, кількість членів товариства зростала не так швидко, і голова товариства I. Наумович був змушений кілька раз вибачитися за таке рішення. Вперше він це зробив на надзвичайних загальних зборах у січні 1876 p. $^{78}$, а в "Науці" визнав, що слід було друкувати перші книжечки накладом максимум 5000 примірників ${ }^{79}$.

Товариство "Просвіта" у 1873 р. друкувала свої популярні книжечки пересічно накладом 3000 примірників; при цьому народовці визнавали, що за кращих умов могли б розповсюдити і 5000 примірників. ${ }^{80}$ У 1874 р. вони вже видавали свої книжечки накладом 5, 8, а деякі навіть 10 тис. прим. і були налаштовані оптимістично ${ }^{81}$. Мабуть, їх колеги і одночасно опоненти з Товариства ім. М. Качковського орієнтувалися, зокрема, і на ці показники. Але

72 “Слово”, 1875, 18 февраля (2 марта) (чис. 18), с. 3.

73 “Слово”, 1875, 5 (17) іюля (чис. 72), с. 3. Перші дві книжечки були надруковані в Коломиї у друкарні Михайла Білоуса, наступні друкувалися вже у Львові в друкарні Ставропігійського інституту.

74 Про це недвозначно заявив і голова товариства І. Наумович: Изъ Скалата..., “Слово", 1875,8 (20) іюля (чис. 73 ), с. 1.

75 Накладом 10000 прим. вийшли перші чотири книжечки, надруковані у 1875 р. (“Слово”, 1877, 4 (16) іюня (чис. 61), с. 3.

76 “Слово”, 1875, 31 мая (12 іюня) (чис. 59), с. 3.

77 О обществъ Качковского, "Наука”, 1875, Май (чис. 5), с. 237-238.

78 Генеральное собраніе членовъ..., "Слово”, 1876, 13 (25) января (чис. 6), с. 1.

79 [И. Наумовичъ], О обществъ Михаила Качковского..., с. 48.

80 Огляд на рік 1873, “Правда”, 1874, 16 (28) лютого (чис. 2), с. 78.

81 Олляд на рік 1874, “Правда”, 1875, 18 (30) січня (чис. 2), с. 78. 
прогнози у цьому питанні були справою дуже непевною - на зростання кількості членів Товариства ім. М. Качковського впливали різні чинники. Про кількість галицьких русинів, які були готові платити за читання популярної русофільської літератури в середині 1870-х рр., може свідчити

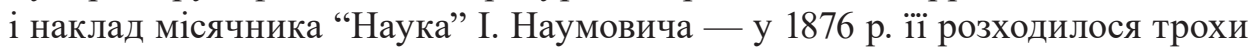
менше 2000 примірників. 82

У будь-якому разі наклад перших видань Товариства ім. М. Качковського виявився завеликим, як і видатки на їх виготовлення. Наприклад, четверта книжечка “Домашній скотъ” обсягом 37/8 арк. коштувала товариству 563 зр. 85 кр., і це без оправи ${ }^{83}$. Як наслідок, на початок 1876 р. товариство мало 746 зр. 89 кр. боргу ${ }^{84}$ і наступний виділ мусив шукати вихід із цієї ситуації.

Члени Товариства ім. М. Качковського протягом першого року його видавничої діяльності (тривав до 3 (15) травня 1876 р.) отримали тільки п'ять книжечок. Цього було мало, їх загальна вартість була меншою за 1 зр. ${ }^{85}$ і чимало членів висловлювали незадоволення. Окрім того, були незадоволені і змістом книжечок ${ }^{86}$, і нерегулярністю їх виходу в світ та розсилки.

Перші видання товариства (як і наступні) були покликані знайомити читачів не тільки із завданнями та перебігом справ Товариства ім. М. Качковського, а й дати інформацію у популярній формі на найрізноманітнішу тематику: від історії Русі до державного устрою Австрії та нових методів господарювання, а також пропонували короткі художні тексти повчально-моралізаторського змісту. Загалом тематичне спрямування видань товариства було традиційним для просвітницьких громадських організацій того часу. Однак брак талановитих авторів (велика проблема для галицької руської літератури 1870-х рр.) і консерватизм русофілів (у багатьох він поєднувався із обмеженістю світогляду) були причиною сірості та банальності більшості (а на думку опонентів русофілів - навіть усіх) видань Товариства ім. М. Качковського. Навіть голова товариства І. Наумович відверто визнавав недоліки його перших видань: “не появилися на разу хорошиิ писатель, книжочки не выходили въ часъ, не конечно основно, лишь такъ, якъ то кажутъ, на прихапци були составлениิ, и въ самоิй експедиціи було много хибы, такъ що терпеливоิсть членоิвъ до крайности злоупотреблялася"87.

Виправити недоліки, де було це можливо, взявся новий склад головного виділу товариства, обраний у січні 1876 р. Вони подали до друку останню,

82 [И. Наумовичъ], Общество Михаила Качковского..., с. 274.

83 Изъ Коломьии..., с. 2.

84 Генеральное собраніе членовъ..., “Слово”, 1876, 10 (22) января (чис. 5), с. 1.

85 Члени товариства отримували книжечки безкоштовно, інші особи могли їх придбати. Вартість перших п'яти випусків складала 10 кр. (окрім більшого за обсягом четвертого, який коштував 15 кр.) (“Слово”, 1877, 27 іюня (9 іюля) (чис. 70), с. 4).

86 И. Наумовичъ, О обществъ Михаила Качковского..., с. 190.

87 [И. Наумовичъ] Общество Михаила Качковского..., с. 277. 
п’яту книжечку за попередній рік (Горитъ! І. Наумовича, вийшла накладом вже 6000 прим.) і розпочали впроваджувати зміни до організації підготовки видань до друку. На засіданні виділу 4 (16) березня 1876 р. було ухвалено, що $з$ початком нового року (тобто 33 (15) травня) книжечки Товариства ім. М. Качковського виходитимуть у світ щомісяця - "избъженія ради большихъ почтовыхъ издержекъ и частьйшого сообщенія ради съ членами" 88 . Трохи згодом обрали з членів виділу спеціальний редакційний комітет із трьох осіб (А. Дольницького, М. Клемертовича та В. Площанського), який під керівництвом заступника голови товариства Є. Мироновича і за участю трьох фахівців із-поза виділу мав готувати до друку книжечки ${ }^{89}$.

Головний виділ мав чіткий намір розпочати з середини травня $1876 \mathrm{p}$. “органичный трудъ” 90 , що мало означати регулярну роботу, поширення на провінції через нові філії та вчасну публікацію та розповсюдження видань товариства. Щомісячний вихід у світ книжечок справді вдалося налагодити: до серпневих загальних зборів у Стрию з'явилося три з них, кожна, обсягом два аркуші, приблизно у другій декаді місяця ${ }^{91}$. I далі книжечки Товариства ім. М. Качковського виходили в світ більше-менше регулярно, інколи 3 незначним запізненням; окремі випуски бували здвоєними (3,5 арк.), за два місяці (головно для заощадження поштових видатків). Їх обсяг був від 32 до 96 с. малого формату $\left(16^{\circ}\right)$. Мова - традиційна для русофільських видань “галицько-руська книжна мова", правопис етимологічний. Загалом, на думку П.Р. Магочі, видання товариства "мали знайомий для селянських мас вигляд, це були “наші”, галицько-руські книжки"92.

Перші десять випусків другого (1876/77) року видання мали наклад 6000 прим., два останні - 6300 прим. ${ }^{93}$ Книжечки третього (1877/78) року видання через збільшення кількості членів товариства видавали накладом 8000 прим ${ }^{94}$. Авторам планувалося, як і раніше, виплачувати гонорар за рішенням головного виділу ${ }^{95}$. Всього протягом $1875 / 76$ р. вийшло 5 випусків

88 “Слово”, 1876, 9 (21) марта (чис. 29), с. 3.

89 “Слово”, 1876, 20 марта (1 апрьля) (чис. 34), с. 3. Трьома запрошеними членами стали о. І. Гушалевич, проф. М. Полянський та д-р Е. Савицький (“Слово”, 1876, 30 марта (11 апрьля) (чис. 38), с. 3).

90 Воззваніе къ пчт. членамъ Общества имени М. Качковского, “Слово”, 1876, 30 марта (11 апрьля) (чис. 38), с. 1.

91 “Слово”, 1876, 12 (24) іюня (чис. 67), с. 3 ; 6 (18) іюля (чис. 76), с. 3; 9 (21) августа (чис. 90), c. 3.

92 П. Р. Магочій, Культурні організації..., с. 196.

93 “Слово”, 1877, 4 (16) іюня (чис. 61), с. 3.

94 “Слово”, 1877, 18 (30) іюня (чис. 67), с. 4; О.А. Мончаловскій, Памятная книжка въ 25-лґтній ювилей..., с. 125.

95 Платили не всім авторам і не за всі тексти. У 1876 р. (січень-серпень) авторам та коректору виплатили 22 зр. (Выказъ приходовъ и росходовъ Общества имени Михаила Качковского за время отъ 8 (20) Января до 31 Іюля (12 Августа) 1876 г., [в:] И. Наумовичъ, Го- 
(5 книжечок), 1876/77 p. - 12 випусків (11 книжечок), до загальних зборів 2 жовтня 1877 р. - 4 випуски (3 книжечки).

На засіданнях головного виділу Товариства ім. М. Качковського видавничу тематику обговорювали регулярно, але йшлося головно про технічні деталі, передовсім терміни виготовлення та розповсюдження тієї чи іншої книжечки. Інколи виділ вирішував учергове звернутися до потенційних авторів із закликом надсилати рукописи та до агентів і філій товариства, аби вчасно передавали нові випуски членам товариства. Із цим були проблеми, бо не всі філії (в особі їх керівників чи секретарів) вчасно розсилали книжечки, що викликало нарікання членів. У такому випадку головний виділ був змушений висилати книжечки членам товариства напряму, хоча це було невигідно, бо збільшувало поштові видатки та час на ведення експедиції ${ }^{9}$.

Видання Товариства ім. М. Качковського можна було придбати особам, які не були членами товариства. Це, щоправда, стосувалося всіх п'яти книжечок першого року видання і тільки однієї другого року видання ${ }^{97}$. Інші книжечки другого року видання планували тільки роздавати членам товариства $^{98}$. Придбати книжечки Товариства ім. М. Качковського можна було в офісі товариства, по філіям та в окремих книгарнях. Філії отримували 3 продажу комісію в розмірі $20 \%{ }^{99}$, а в книгарнях ціна на видання товариства мала бути більшою, ніж у філіях ${ }^{100}$. Особливим із видань $1876 / 77$ р. був випуск 9-10 “Изданій Общества имени Михаила Качковского” - Дядько Өома Ореста Авдиковського. Це була переробка частини відомої повісті Гаррієт Бічер-Стоу Хатина дядька Тома. 3 уваги на те, що цей твір був дуже відомий, товариство сподівалося на підвищений попит і тому видало вип. 9-10 додатковим накладом 2000 прим. (окрім звичних 6000 прим. для членів).

ритъ!..., с. 95), у 1876/77 р. - 163 зр. 80 кр. (Пятое генеральное собраніе..., “Слово”, 1877, 22 сентября (4 октября) (чис. 103), с. 2). Найбільший гонорар за чотири “повістки” отримав Євген Згарський - 50 зр. (“Слово”, 1876, 7 (19) октября (чис. 113), с. 3).

96 “Слово”, 1877, 14 (26) мая (чис. 53), с. 3.

97 Окрім періодичних щомісячних книжечок для своїх членів Товариство ім. М. Качковського у 1877 р. підтримало видання ще однієї книжки: “Поезіи” Євгена Згарського. 3 автором (і членом редакційного комітету товариства) було укладено якусь угоду про співпрацю, і Товариство ім. М. Качковського взяло на себе видатки на виготовлення цієї книжки (180 зр.). Угоди, однак, Є. Згарський не дотримав, а кошти видання ще довго тяжіли як борг товариства перед Ставропігійським інститутом (див. листування по цій справі в 1885 р. у: Центральний державний історичний архів України, м. Львів, ф. 129, оп. 2, спр. 1135, арк. 18-19). Продаж цієї книжки (вартістю 30 кр.) зовсім не зміг компенсувати видатки.

98 “Слово”, 1877, 19 февраля (3 марта) (чис. 19), с. 3.

99 “Слово”, 1877, 27 іюня (9 іюля) (чис. 70), с. 4.

100 “Слово”, 1877, 19 февраля (3 марта) (чис. 19), с. 3. Відомо, що книжечки Товариства ім. М. Качковського у 1877 р. можна було придбати у книгарні Ставропігійського інституту у Львові, а також у книгарнях Губриновича і Шміта в Львові та Чилліка в Тернополі. Товариство співпрацювало, очевидно, і з іншими книгарнями. 
Саме цей додатковий наклад мали продавати по філіях та книгарнях по ціні 25 кр. ${ }^{101}$ Загалом продаж видань не був серед провідних напрямів діяльності товариства і приносив невеликі прибутки (тільки 60 зр. 81 кр. у 1876/77р.) . $^{102}$.

Зміст видань товариства на засіданнях головного виділу, як правило, не обговорювали - цим займався редакційний комітет. У 1876/77 р. до нього входили з виділу М. Полянський, В. Площанський та М. Клемертович, а 3-поза нього Є. Згарський та Е. Савицький ${ }^{103}$. Стратегічно видавничу програму мали б корегувати загальні збори Товариства ім. М. Качковського. Однак на них, як це не дивно на перший погляд, видавничі питання майже не обговорювали. У 1875 р. в Галичі хіба що студент Михайло Павлик (згодом відомий діяч-радикал) запропонував зайнятися перекладом Св. Письма народною мовою (пропозицію відхилили) ${ }^{104}$. На надзвичайних загальних зборах у Львові в 1876 р. той само М. Павлик вимагав “чтобы общество старалось въ своихъ изданіяхъ популяризовати розныи отрасли наукъ и чтобы вмъсто строгихъ моральныхъ увъщаній старалось поучати народъ наглядными примърами, взятыми изъ жизни народной” (пропозицію залишили на розгляд виділу) ${ }^{105}$. У 1876 р. в Стрию о. Стефан Ленкавський рекомендував головному виділу зайнятись виданням т. зв. “домашняго правотаря”, тобто юридичного порадника для простолюду ${ }^{106}$. I все, у 1877 р. загальні збори взагалі не обговорювали видавничі питання.

Таке ігнорування видавничої тематики на загальних зборах показове. Члени Товариства ім. М. Качковського, не тільки селяни, а й інтелігенти, були не готові обговорювати деталі видавничої програми. Все залишали на розсуд головного виділу, навіть редакційного комітету товариства. Там більше турбувалися, аби книжечки просто вчасно виходили в світ. Тому комітет працював із тими текстами, які надсилали автори. Як правило, це були або науково-популярні компіляції, або моралізаторські художні твори. Активної і кваліфікованої критики видань товариства у русофільському середовищі не було. Натомість галицькі народовці у “Правді” детально розбирали зміст і спрямованість книжечок Товариства ім. М. Качковського ${ }^{107}$. Оцінки украї-

101 “Слово”, 1877, 3 (15) марта (чис. 24), с. 3; 12 (24) марта (чис. 28), с. 3. Із 12 (24) вересня 1877 р. вартість цієї книжечки знизили до 20 кр. (“Слово”, 1877, 13 (25) вересня (чис. 100), c. 3).

102 Пятое генеральное собраніе членовъ..., “Слово”, 1877, 22 сентября (4 октября) (чис. 103), с. 2.

103 “Слово”, 1876, 18 (30) сентября (чис. 106), с. 3.

104 Отчетъ изъ второго генерального собранія..., "Слово”, 1875, 19 (31) августа (чис. 89), с. 1.

105 Генеральное собраніе членовъ..., “Слово”, 1876, 15 (27) января (чис. 7), с. 1.

106 Третье генеральное собраніе..., “Слово”, 1876, 12 (24) августа (чис. 91), с. 2.

107 Книжечки 1876/77 р. розглянуто у: “Правда”, 1877, 18 (30) червня (чис. 12), с. 455-462; 3 (15) липця (чис. 13), с. 493-499; 19 (31) липця (чис. 14), с. 539-547; 3 (15) вересня (чис. 17), 
нофілів були жорсткими, вони відзначали безідейність, змістову убогість, численні помилки у популярних виданнях конкурентів і називали їх просто “дрантям" 108.

Результати роботи Товариства ім. М. Качковського у 1874-1877 pp. Діяльність русофільського просвітницького товариства насамперед свідчить про стан руського громадського, культурного та інтелектуального життя в Галичині у 1870-х рр. Дуже виразною тоді стала необхідність морального і матеріального розвитку руського селянства; шпальти руських часописів були переповнені текстами про важкий стан селянства і його неминучий занепад за відсутності будь-яких дій. Вже давнє гасло просвіти народу стало по-новому актуальним і знайшло відгук у принаймні частини руської інтелігенції.

Як наслідок, з'явилося Товариство ім. М. Качковського, перші результати якого оцінювали неоднозначно. Руські публіцисти 1870-х рр. часто кидалися в крайнощі, щирий ентузіазм та захоплення першими успіхами межували із жорсткою критикою, перебільшенням недоліків та навіть елементами розпачу. Якщо ж спробувати відсторонено проаналізувати результати перших років діяльності Товариства ім. М. Качковського, то вони видаються цілком успішними.

На відміну від “Галицько-руської матиці", це товариство стало результатом ініціативи знизу, із провінції. Не маючи помітної підтримки лідерів галицьких русинів (правда, і протидії не було), окремі діячі створили і за короткий час розбудували громадську організацію, яка за кількістю членів стала найбільшою серед руських товариств у Галичині. При цьому Товариство ім. М. Качковського не відчувало підтримки ні з боку крайової влади (на відміну від “Просвіти”, яка на початку свого існування отримувала субсидії від Галицького сейму), ні з боку меценатів. Безумовно, видатною була роль І. Наумовича - без нього таке товариство не заснували б.

Галицьке руське селянство на чолі зі своїми священиками виявилося спроможним утримати таке товариство - це було новим і дуже позитивним явищем для русинів 1870-х рр. Звичайно, діяльність Товариства ім. М. Качковського зі свого боку у відповідь сприяла підвищенню рівня знань, громадянської та національної свідомості руських селян та міщан, їх соціальній організації. Інтелектуальний рівень видань та закладені в них ідеї спочатку не мали принципового значення - сам факт існування такого товариства,

с. $657-660 ; 3$ (15) жовтня (чис. 19), с. 730-734; 18 (30) жовтня (чис. 20), с. 776-779; 18 (30) листопада (чис. 22), с. 853-856; 18 (30) грудня (чис. 24), с. 943-945.

108 "Ми [...] запитаємося: що зискав, чого доброго навчився наш нарід с тих всіх книжочок в 24 аркушів друку? Як сі книжочки безпосередно не пошкодили справі просвіти народноі, то шкодять посередно, бо зражають нарід до популярних книжочок в загалі и тим заподівають превелику шкоду! Лучше видати на 4-ох аркушах до року що доброго, ніж 24 аркуші дрантя!” (“Общество имени Михаила Качковского”..., с. 744). 
його книжечки, численні загальні збори, небачені раніше філії та читальні були новими для селян і привертали їх увагу. На першому етапі цього було достатньо. 3 часом первісний ентузіазм мав ослабнути, що й сталося.

Найбільшою проблемою Товариства ім. М. Качковського було те, що воно виявилося занадто русофільським і консервативним. Первісні наміри орієнтуватися на досвід інших народів та побажання бути понадпартійною організацією не вдалося реалізувати. Запозичення досвіду просвітницьких товариств 3-поза Галичини не було помітно - згадані в цій статті чеське та словенське товариства залишилися радше теоретичним орієнтиром. Образно кажучи, Товариство ім. М. Качковського не змогло стрибнути вище голови і сформувалося як глибоко провінційна (в масштабі Австро-Угорщини) і консервативна громадська організація. Опоненти дорікали невідповідним рівнем керівників товариства, вузькістю їх світогляду — i слушно. Однак, талановитих, прогресивних і креативних діячів серед галицьких русинів було надто мало. Тому головний виділ зосередився передовсім на дисциплінованій підтримці регулярної роботи, а для цього вистачало й сумлінних клерків.

Змістове та ідейне підгрунтя діяльності Товариства ім. М. Качковського формувалося все-таки не у Львові — його визначала передовсім провінція. Це були греко-католицькі священики і окремі найактивніші селяни. Їх розуміння просвіти народу, насамперед через побожність, молитву, моральність, повагу до держави і Церкви, старанну працю, а далі вже через нові знання (але без глибоких соціальних перетворень), визначало зміст видань товариства. Національну просвіту розглядали головно як утвердження поваги до історії Русі, руської літературної мови, віри та східного обряду. 3 точки зору лібералів та поступовців ці видання були глибоко застарілими, русофіли ж їх вважали виваженими і такими, що краще підходять читачам із простолюду.

На жаль, брак талановитих авторів значно зашкодив Товариству ім. М. Качковського повноцінно відтворити свою просвітницьку програму (яка існувала, правда, радше на рівні уявлень, а не чітко визначених тез) у книжечках для своїх членів. Художні твори були, як правило, невисокого естетичного рівня та ідейно застарілі. Науково-популярні тексти і господарські рекомендації, нехай і часто механічно скомпільовані, були більше корисними.

Товариство ім. М. Качковського протягом перших років свого існування не відчувало сильної видимої конкуренції. Існування “Просвіти”, незважаючи на гостру критику українофілів, намагалися не помічати, також не надавали значної ваги польським виданням для простолюду, які поширювалися i серед русинів. Лише з початку 1880 -х рр., після заснування "Польської Матері" ("Macierz Polska"), русини зіткнулися із серйозною конкуренцією з польським просвітницьким проектом серед галицьких селян. 
Отже, Товариству ім. М. Качковського протягом перших років свого існування вдалося налагодити досить розгалужену організаційну структуру та регулярну видавничу діяльність і позитивно вплинути на розвиток передовсім руського простолюду в Галичині, однак кадрова бідність та ідейна обмеженість не сприяли подальшому зростанню. Вже 3 кінця 1870-х рр. настала стагнація, а потім навіть часткова втрата здобутих позицій; лише наступному поколінню громадських діячів наприкінці XIX ст. вдасться у нових умовах досягти помірного прогресу.

ОЛЕКСАНДР СЕДЛЯР (OLEKSANDR SEDLÂR)

\section{THE FOUNDING AND FIRST FEW YEARS OF THE MYKHAILO KACHKOVSKI} SOCIETY

Summary

The Mykhailo Kachkovsky Society, founded in 1874 in Kolomyia, quickly became one of the main public organisations of Galician Ruthenians. It was founded by the local Russophiles on the initiative of a Greek Catholic priest, Ivan Naumovych. The Society was involved in educating Ruthenian peasants and townspeople, it promoted new forms of organising the economy and raised civic and national awareness of Galician Ruthenians. The Kachkovsky Society competed against the Ukrainophile Prosvita and (from the 1880s) with Polish education societies in Galicia. Its main activity was publication of books of up to 100 pages (from 1876 on a monthly basis) for members of the society. They featured short moralising pieces, articles about history (of Ruthenia), information about the world as well economic and legal advice. The article examines a period from the founding of the Kachkovsky Society in 1874 till 1877, i.e. when it was headed by its initiator and founder, Fr Naumovych. Initially, the society was based in Kolomyia, but when it turned out that there were not enough people to ensure the right organisation for the society, in early 1876 its offices were moved to Lviv. In 1876-1877 representatives of the society founded a dozen or so branches across Galicia, which contributed to an expansion of its activity and organisational structures: in 1877 the Kachkovsky Society had about 6,500 members.

KEY WORDS: The Mykhailo Kachkovsky Society, Galicia, Galician Russophiles, popular literature, Ivan Naumovych 